\title{
Community Engagement in the Greater Lumbini Area of Nepal: The Micro-Heritage Case Study of Dohani
}

\author{
Nick Lewer, Anouk Lafortune-Bernard, Robin Coningham, \\ Kosh Prasad Acharya and Ram Bahadur Kunwar
}

Abstract This chapter describes the historical and modern importance of the Greater Lumbini Area of Nepal from the perspective of its many large and small archaeological sites, and the importance of preserving and protecting its living cultural heritage. Issues include the impact of industrial infrastructure development and a corresponding increase in

N. Lewer $(\square)$

Coral Associates Ltd, North Yorkshire, UK

e-mail: nick.lewer@coralassociates.org

A. Lafortune-Bernard · R. Coningham

Durham University, Durham, UK

e-mail: anouk.lafortune-bernard@durham.ac.uk

R. Coningham

e-mail: r.a.e.coningham@durham.ac.uk

K. P. Acharya · R. B. Kunwar

Department of Archaeology, Government of Nepal, Kathmandu, Nepal

(C) The Author(s) 2019

R. Coningham and N. Lewer (eds.), Archaeology, Cultural

Heritage Protection and Community Engagement in South Asia, https://doi.org/10.1007/978-981-13-6237-8_5 
air pollution, the positive and negative impact and opportunities as a result from a rise in tourism (particularly pilgrims), encroachment, and the needs of community economic benefit. Using Dohani as a case study, the approaches and methodologies used for community consultation and engagement in heritage protection at a micro-heritage site are described and their effectiveness considered. Challenges for the community include those of motivation, sustainability, coordination between agencies, governance and the role of volunteers.

Keywords Nepal $\cdot$ Dohani $\cdot$ Community $\cdot$ Heritage protection

\subsection{INTRODUCTION}

This chapter focuses on the historical and modern importance of the Greater Lumbini Area (GLA)of Nepal within the context of its many archaeological sites and the importance of preserving and protecting its living cultural heritage. Issues include the impact of infrastructure development and the positive and negative impact and opportunities that arise from the rise in tourism, particularly pilgrims. Referencing Dohani as a case study, the approaches and methodologies used for community consultation and engagement in heritage protection at a micro-heritage site are described and their effectiveness considered particularly in relation to how communities living nearby may benefit socially, spiritually and economically from archaeological activities. We acknowledge the generosity of Durham University and Durham's UNESCO Chair in allowing this chapter to be made Open Access to reach and influence as wide an audience as possible.

\subsection{The Greater Lumbini Area (GLA)}

\subsubsection{Demographics}

The GLA, with its rich tangible and intangible Buddhist heritage, is located in Nepal's western Terai and stretches across the districts of Nawalparasi, Rupandehi and Kapilbastu. Recently incorporated into Nepal's new Federal Province No. 5, identity groups include indigenous peoples such as the Tharu communities and those who have migrated 
Table 5.1 Overview of the population of the Greater Lumbini Area based on Nepal's 2011 National Population Census Data

\begin{tabular}{lccc}
\hline $\begin{array}{c}\text { Rupandehi } \\
\text { District (\%) }\end{array}$ & $\begin{array}{l}\text { Kapilbastu } \\
\text { District (\%) }\end{array}$ & $\begin{array}{l}\text { Nawalparasi } \\
\text { District (\%) }\end{array}$ \\
\hline Hindu & 86 & 81 & 88 \\
Muslim & 8 & 18 & 4 \\
Other & 6 & 1 & 8 \\
\hline
\end{tabular}

to the Terai over the last century, mainly from the hill regions of Nepal and from India (Whelpton 2005; Gaige 2009). The population is predominantly Hindu with a significant Muslim minority, but few Buddhists (Table 5.1).

Economic activity in the GLA is primarily agricultural but industry is developing along the highways and in cities, particularly in Rupandehi District (CBS 2014a). Kapilbastu is the least advanced of the three districts with numerous developmental challenges including weak governance, communal tensions between Hindu and Muslim communities as well as with recent internal migrant groups, flooding during the monsoon, and the prevalence of traditional practices of caste and gender-based discrimination (CBS 2012a, b; 2014a, b, c, d; UNDP and Government of Nepal 2014).

\subsubsection{Buddhist Heritage}

Rupandehi District is home to the garden of Lumbini, birthplace of the Buddha, which he identified as one of four sites that his disciples should visit on pilgrimage. The other three are in modern India: Bodh Gaya, where he found enlightenment; Sarnath, where he gave his first teaching; and Kusinagara, where he attained parinirvana or 'great passing away' (Weise 2013). Kapilbastu District has other important sites linked to early Buddhism, including Tilaurakot, thought to be ancient Kapilavastu, childhood home of the Buddha and capital city of his father Suddhodana. Sandstone pillars at Gotihawa and Niglihawa record early royal patronage and pilgrimage to Buddhist sites as they reference, as does the pillar at Lumbini, visits from the Emperor Asoka in the third century BCE (Coningham et al. 2015). The last of these major sites is 


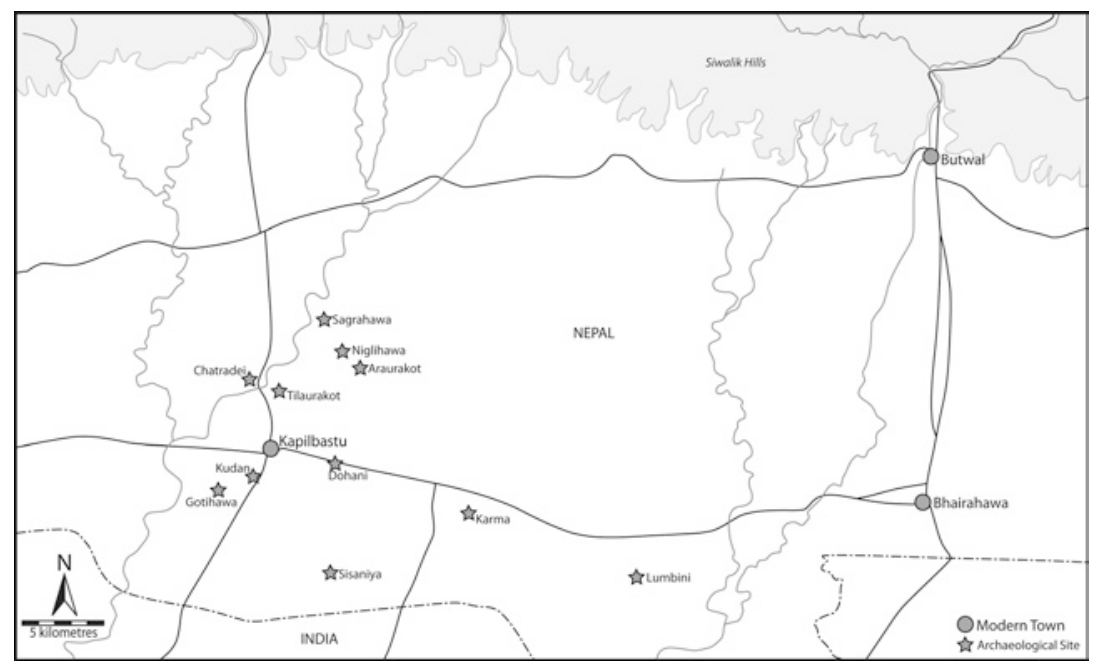

Fig. 5.1 Map of key heritage and archaeology sites within the Greater Lumbini Area

the stupa at Ramagrama in Nawalparasi District, believed to be one of the first stupas built after the Buddha's parinirvana and the only one that has remained unopened, thus containing an original share of his corporeal relics (Fig. 5.1).

These locations were identified in the late nineteenth century during explorations to rediscover Buddhist sites mentioned in historical and religious texts (Allen 2008; Coningham 2001; Führer 1972; Mukherji 1901). However, little research had been undertaken until the late 1960s when, with UN support, initiatives began to develop Lumbini as an international centre of pilgrimage and tourism (Joury 1969). The Lumbini Master Plan (LMP) was finalized in 1978 (Tange \& URTEC 1978) and is being implemented by the Lumbini Development Trust (LDT). While Lumbini was included on UNESCO-'s World Heritage list in 1997, other Nepali sites remain at the edge of larger pilgrimage circuits, primarily centred around Lumbini and Indian centres such as Bodh Gaya, Rajgir, and Sarnath (Table 5.2). However, with the LMP reaching its final stage of implementation and visitor numbers expected to reach two million by 2020 , there is interest in the development of other Nepali sites as part of the GLA's economic development. 
Table 5.2 Annual visitor numbers at selected sites within the Buddhist circuits of north-east India and Nepal

\begin{tabular}{lrrrrr}
\hline Sites & ${\text { Bodh } \text { Gaya }^{\mathrm{a}}}$ & Sarnath $^{\mathrm{b}}$ & Rajgir $^{\mathrm{a}}$ & Lumbinic $^{\mathrm{C}}$ & Tilaurakot $^{\mathrm{C}}$ \\
\hline Numbers & $2,040,625$ & $1,455,271$ & $1,683,723$ & $1,550,000$ & 38,239 \\
\hline
\end{tabular}

a Source Bihar Tourism Statistics 2018

${ }^{\mathrm{b}}$ Source Uttar Pradesh Tourism Statistics 2018

'Source Lumbini Development Trust

\subsubsection{Economic Development}

The GLA's Buddhist archaeological heritage has been highlighted as a key development asset (UNFCO 2013: 11). As a result, the World Bank/International Finance Corporation and Asian Development Bank $(\mathrm{ADB})$ are upgrading regional infrastructure, including road widening and transforming Bhairahawa airport into an international facility (ADB 2018a, b; IFC 2013). Their objectives also include the improvement of infrastructure at key heritage sites, the development of a promotional plan, and support for business initiatives (TRC 2013; ETG 2013; CTCA 2014). Interest from international Buddhist stakeholders has increased with, for example, the construction of new monasteries at Tilaurakot and Kudan in Kapilbastu District under the auspices of Lumbini's Royal Thai Monastery. However, visitor number growth, along with accelerated development in the GLA, has adversely affected the preservation of archaeological sites and impacted on local communities (Coningham et al. 2017). One unwelcome spin-off is an increase in environmental degradation and air pollution as industry has spread along upgraded road networks (Vivekanda 2017).

In 2013, an Integrated Management Plan (IMP) was prepared for Lumbini with the aims of redefining the management framework of Lumbini and planning future local and regional initiatives to ensure the sustainable development of the GLA. Other objectives included research and development of sites while prioritizing conservation and facilitating 'strategies for poverty alleviation of the local communities and to develop tourism and pilgrimage by means of improving facilities, services, infrastructure and accessibility of heritage sites' (Weise 2013: 7). The IMP proposed applying for World Heritage Site status for Tilaurakot 
and Ramagrama to provide more diversity for visitors and to promote the Terai as an important destination for cultural and religious tourism. Following the IMP's recommendations, the Japanese-Fund-in-Trust-forUNESCO Project Strengthening the Conservation and the Management of Lumbini, Birthplace of Lord Buddha, World Heritage Site, Phase 2 (2014-2017), under the overall leadership of Professor Yukio Nishimura of the University of Tokyo, began a programme of multi-disciplinary research in Kapilbastu District, with Tilaurakot as its main location, focused on three aspects: archaeological investigations, conservation, and design and planning (Coningham et al. 2017). An associated programme was also developed to start mapping the perceptions and use of archaeological and sacred sites by users and stakeholders, and how these may be impacted by excavations and other interventions (LafortuneBernard et al. 2018a, b). This data is being used to help understand the balance between the protection of ancient heritage with local communities and visitor needs. For example, in some places encroachment and soil extraction were degrading heritage, and this required consultation and participation of local communities to resolve. At Kudan, a fence had been built between the archaeological site and the local village in an effort to protect the site from cattle, but which separated the people from a shrine that was in daily use - an example of an 'outside' heritage protection initiative that introduced separations which did not exist previously between residents and their living heritage. Such observations emphasized the importance of strengthening community participation in site custodianship to ensure that connected communities benefit from, or at least are not harmed by, archaeological needs (Coningham et al. 2017).

\subsection{DOHANI}

Dohani is located six kilometres south-east of Tilaurakot on the main Taulihawa-Lumbini road. In 2011 the population of Dohani was 6721 with 27 different caste, religious or ethnic groups and seven mother tongues spoken, mainly Awadhi and Urdu, with very few native Nepali speakers. In terms of identity, 30\% were classified as lower caste; $20 \%$ Muslim; 20\% Yadav; 15\% Kurmi; and 15\% others (CBS 2014b). Dohani's social capital is rich and includes CBOs and NGOs such as women's microcredit groups, a child rights group, Siddhartha Community Development which promotes children's education, a youth cricket club; Dalit 
Association; Farmer's Cooperative; Mothers' Group; Ward Citizen Forum; Citizen Awareness Centre; and the Poverty Alleviation Cooperative. It has four government schools, four private schools and four madrasas.

The main livelihood is derived from agriculture, with some employment in public service, businesses such as a rice mill, teashops and food shops, sewing, pottery, fish farms and rice-frying. Most people own their homes and have land that is used for domestic vegetable and crop production. The main road through Dohani has been widened to improve connections between Lumbini and Kapilbastu District, especially Taulihawa and Tilaurakot. With envisaged increases in visitor numbers, there is the potential for Dohani to become an attraction for pilgrims travelling between Lumbini and Tilaurakot.

The archaeological site of Dohani is demarcated by a fence with a boundary of about 1.5 kilometres and comprises uncultivated land containing a broad low mound, threshing areas, haystacks and has cattle grazing on it. Within the site, there is a local shrine dedicated to the goddess Samai Mai. Archaeological investigations started in 2015 when a team from the Japanese-Funds-in-Trust-for-UNESCO project and the Department of Archaeology (DoA) completed a geophysical survey and identified a small square clay fortification with rounded towers at each corner (Fig. 5.2). The DoA then excavated in 2017 and 2018,

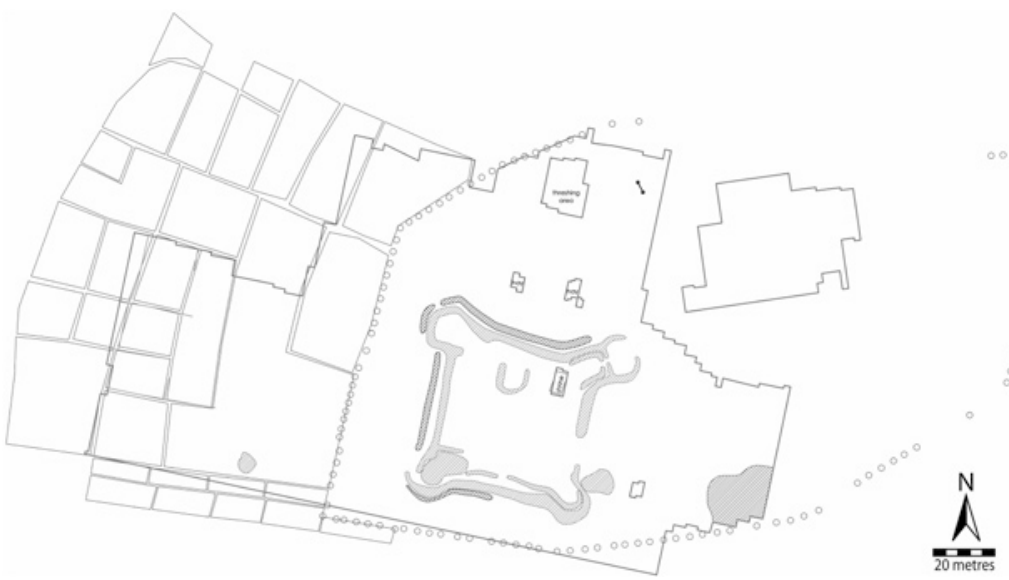

Fig. 5.2 Plan of the archaeological site of Dohani with geophysical survey overlay 
exposing part of the eastern fortification wall. Evidence of early occupation dating back to the first millennium BCE was recovered, followed by the later establishment of the small fort during the Kushana Period (100 BCE-300 CE). Dohani's location, and that of a similarly shaped monument at Karma, suggests that it functioned as a waystation for people moving along the old pilgrim road between Lumbini and settlements to its west.

\subsection{Dohani Community Consultation and Engagement}

\subsubsection{Purpose and Methodology}

The key objectives of consultation are to carry out discussions with communities to explore ways in which people can be collaboratively involved in the protection of an archaeological site, and to discuss the future development of tourism and pilgrimage so that local people may benefit economically while protecting their own cultural heritage and social values.

Before the community consultation at Dohani began, a survey team was constituted with the LDT, DoA officers and volunteers from local schools and administrations, and a training programme was organized to prepare them for community interviews. This consisted of site visits to Dohani and Kapilvastu, when the significance of the sites was explained, a questionnaire was reviewed and refined, and processes for working in small teams discussed. Six interview teams with three people in each were formed.

The methodology used at Dohani employed individual and household interviews using a questionnaire that allowed for open and closed questions, and with space for discussion; focus groups with women, youth and men; key informant interviews; and random 'informal' meetings. Questions explored a range of issues asking, for example, about any history of illegal soil quarrying close to site boundaries; encroachment; land ownership; economic and trading factors related to development; peoples knowledge of the site; community development needs (education, economic, infrastructure etc.) in relation to future archaeology excavations and potential pilgrimage activity; usage of site by people; existing craft manufacture; markets; and skill availability. Follow-up visits and meetings were held to monitor and discuss changes in community engagement as a result of these consultations. 


\subsubsection{Community Consultation Findings}

Interviews at Dohani indicated that:

- People knew little about the site except for the Samai Mai shrine and its use for occasional social gatherings. Samai Mai is a powerful goddess who villagers worship regularly but the biggest festival occurs during the poya full moon at Vesak when people who have had their wishes fulfilled go to the shrine to give offerings. People also walked around the shrine in the event of smallpox outbreaks. If the elephants get broken, the village repairs it. There is also a tradition for newly married couples to visit Samai Mai. The current shrine on the archaeological mound was built by a Saddhu 15 years ago but has a longer history. The Saddhu has since died but his brother and nephew still care for it.

- The site was used for livestock grazing, threshing, hay storage and as a toilet for some nearby houses.

- It received few visitors from outside Dohani.

- People were curious to learn more.

- The land demarcated by DoA markers was generally respected (Lewer and Lafortune-Bernard 2017).

The community consultation was used to identify potential partners with whom archaeologists could develop a programme to engage residents with the site development and protection. Teachers from schools in Dohani were very helpful and discussions with them highlighted constraints and opportunities to their engagement in helping with the care of the site:

- They had little knowledge about the local heritage and ancient history of the region, particularly early Buddhism;

- There was a lack of educational material for teaching school children about the heritage and the history of the region;

- It was difficult to organize site visits to nearby archaeological sites, like Tilaurakot and Kudan, due to limited funds and transportation costs. Another problem was availability of a knowledgeable guide to provide information about the sites;

- The presence of archaeologists at the site was seen as an opportunity to start designing activities for the schools and local community. 


\subsubsection{Community Engagement}

\subsubsection{First Excavation Season (Jan-Feb 2017)}

A meeting was organized at which teachers, DoA officers, and a facilitator from Durham's UNESCO Chair attended. The main outcome was that participants agreed to form a Community Group with the objectives of helping protect Dohani and raising awareness about local heritage. A series of actions were identified for each partner to support the creation of the Group and its activities, and a Committee was formed to write a constitution. This meant that the Group could be registered with the District Office thus giving access to funding sources. The Durham facilitator and DoA officers agreed to write a booklet on the archaeological heritage of the region as a teaching resource and also a leaflet on the archaeological site, to be finalized in collaboration with the Committee at the following excavation season (January-February 2018). DoA officers gave a site tour to all participants providing information on the site and the latest findings. Follow-up meetings were organized to support the Committee in preparing District Office registration and to discuss the organization of a joint event to mark the end of the archaeological field season in Dohani. The Committee also organized an event for the site visit of the Japanese-Funds-In-Trust-for-UNESCO International Scientific Committee at which the archaeologists had prepared a temporary exhibition of excavated artefacts.

\subsubsection{Second Excavation Season (Jan-Feb 2018)}

The Committee reported that there was difficulty with the process of registering the Group with the District Office due in part to the restructuring of regional and local administrations in Nepal as a result of the process of Federalization (Accord 2017). It was decided to invite the newly elected Ward Chair to become Patron of the Committee and to ask the new Ward to become a partner and to provide support to the teachers in their interaction with the appropriate government offices. Governance restructuring integrated Dohani within Kapilavastu Municipality and it was agreed necessary to assess the potential interest of Municipal offices, local CBOs and NGOs to support the activities of the Committee.

As well as actions taken to establish more permanent structures and resources for the Committee, progress was made in developing educational material for dissemination by teachers. A first version of the 
booklet and leaflet were finalized with the Committee and are currently (June 2018) being tested for one year at Dohani schools and, drawing from teachers' feedback, these will be revised during the next field season (January 2019). The DoA arranged a site visit for staff and school students from Dohani to further stimulate awareness and interest. The President of the Dohani Committee was involved in the organization of the 'Tilaurakot Heritage Festival', an event jointly organized by Durham's UNESCO Chair, the LDT and DoA in collaboration with an Organising Committee composed of local teachers and Kapilavastu Municipality's Education Officer. At the festival, Dohani school students participated in drawing and speech competitions.

\subsection{Conclusion}

New micro-heritage sites like Dohani, that are overshadowed by macro-heritage destinations such as Lumbini and Tilaurakot, present particular challenges. Persuading local communities to engage in heritage protection is difficult when there is initially little evidence of a more permanent visitor attraction and there is no immediate benefit economically. Dohani is a majority Hindu community with little recent Buddhist heritage, so there is a social and spiritual disconnect with the ancient Buddhist pilgrimage history, and the community associates more with the Samai Mai shrine and this is their more powerful contemporary and experiential focus. As excavations proceed, and uncovering more of the site's heritage, it will be interesting to see if such discoveries affect people's view of their identity and connections with the wider society (Fig. 5.3).

As we noted in the Introduction to this book, community-led processes take time and require a long-term commitment of support so that they develop in depth. Providing consistent and sustainable support to the Dohani Committee was problematic. Bursts of activity happened during the fieldwork phases and this stimulated people's interest and allowed contact with archaeologists, but after the site had been closed and the excavation team departed interests waned. Protection at micro-heritage sites may rely on volunteers and it is important to look at what motivates people to take on an unpaid role as it might be that they see business, social and/or spiritual benefits. DoA personnel had sporadic contact with the Dohani Committee between excavations and a Facebook Page was established which provided news and photographs. 


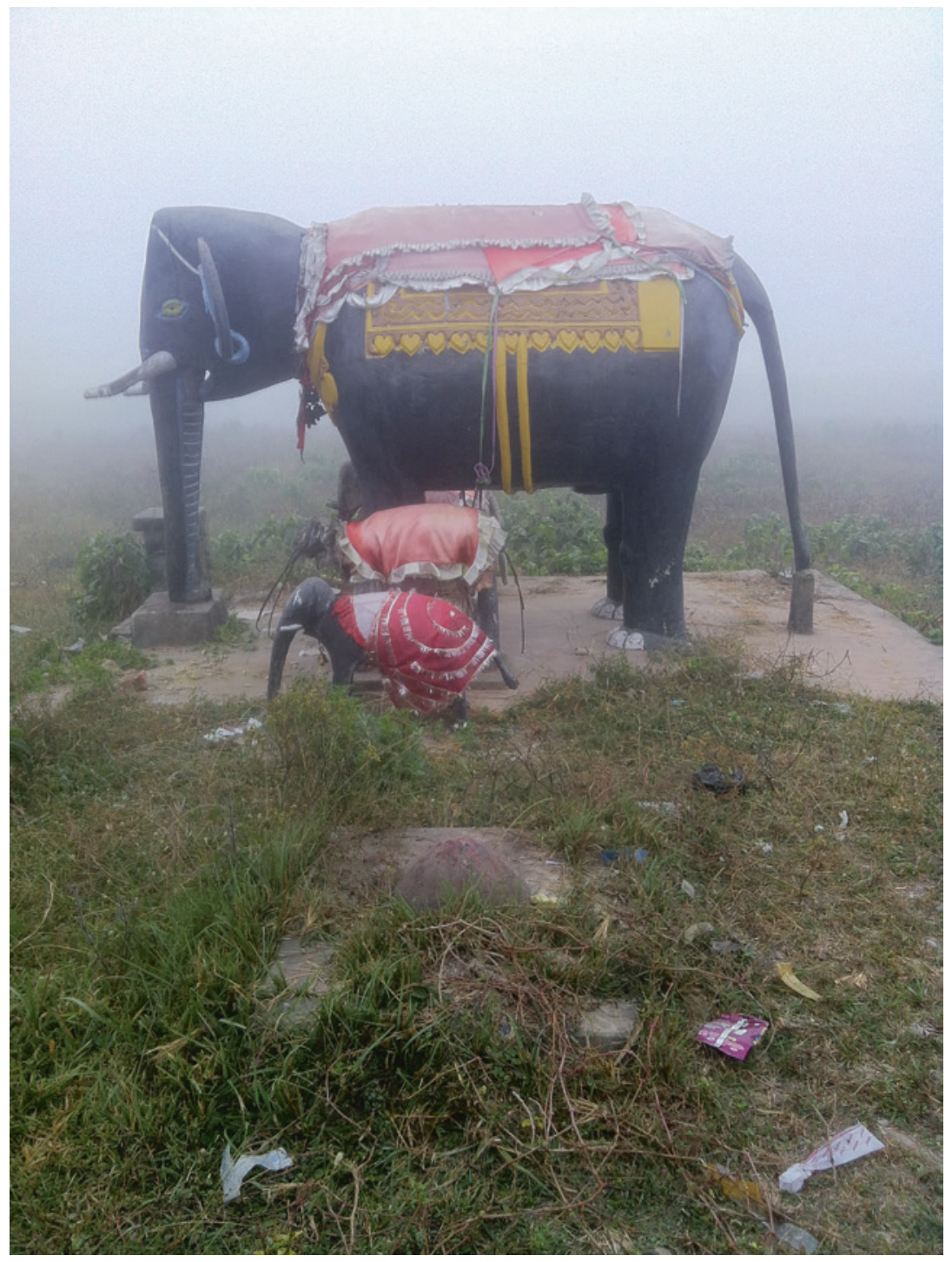

Fig. 5.3 Samai Mai Shrine at Dohani archaeological site 
What is also clear is that the integration of the different levels of governance (local, regional, national, international) is needed to ensure that there is complementarity of actions between archaeological excavations and protection measures with the wider economic and development infrastructure plans. This means regular consultation between the local community, business and tourism sectors perhaps designing an integrated framework for these factors. The DoA is particularly well placed to take the role of lead coordination agency for this.

We agree with Weerasinghe (2017) that heritage value lies in a combination of the archaeological, the natural and the traditional. Collaborating with individuals and organizations specializing in understanding community social capital and social fabric to undertake a more in-depth study of the Dohani community is needed to properly realize these connections. To give credibility to community engagement's claim of putting people at the centre, more effective ways are being explored of bringing Dohani's community into archaeological project conceptualization and management, 'academic' platforms, and dissemination conferences so that their voice is meaningfully heard and listened to. This was, of course, a pilot study but a critical one, to experiment with balancing the needs of macro-heritage sites with potential for enhancing smaller, less prestigious micro-heritage sites and investigate the potential of twintracks for sustainable heritage development. Longitudinal mapping and engagement will allow us to evaluate the success of this pilot and its transferability to similar contexts.

\section{REFERENCES}

Accord. (2017). Two Steps Forward, One Step Back: The Nepal Peace Process. London: Conciliation Resources.

ADB. (2018a). South Asia Tourism Infrastructure Development Project (Bangladesh, India, and Nepal): Project Data Sheet. https://www.adb.org/ projects/39399-013/main\#project-pds.

ADB. (2018b). SASEC Tourism Development Project: Project Data Sheet. https://www.adb.org/projects/39399-012/main\#project-pds.

Allen, C. (2008). The Buddha and Dr Führer: An Archaeological Scandal. London: Haus Publishing.

Bihar Tourism. (2018). Statistics of Domestic and Foreign Tourists Visit to the State of Bihar (Year-2017 January to December). http://www.bihartourism.gov.in/ data/Tourist_Data/Monthly\%20Staticts\%20of\%20Dom\%20and\%20for\%20 final-2017.pdf. 
CBS. (2012a). National Population and Housing Census 2011 (Village Development Committee/ Municipality). Kathmandu, Nepal: Central Bureau of Statistics.

CBS. (2012b). National Population and Housing Census 2011 (National Report). Kathmandu: Central Bureau of Statistics.

CBS. (2014a). National Population and Housing Census 2011 (Village Development Committee/Municipality) Rupandehi. Kathmandu: Central Bureau of Statistics.

CBS. (2014b). National Population and Housing Census 2011 (Village Development Committee/Municipality) Kapilbastu. Kathmandu: Central Bureau of Statistics.

CBS. (2014c). National Population and Housing Census 2011, Volume 5, Part XI: Economic Characteristics Tables. Kathmandu: Central Bureau of Statistics.

CBS. (2014d). National Population and Housing Census 2011, Volume 5, Part III: Social Characteristics Tables (Disability, Literacy Status and Educational Attainment). Kathmandu: Central Bureau of Statistics.

Coningham, R. A. E. (2001). The Archaeology of Buddhism. In T. Insoll (Ed.), Archaeology and World Religion (pp. 61-95). London: Routledge.

Coningham, R. A. E., Acharya, K. P., Kunwar, R. B., Manuel, M. J., Davis, C. E., \& Lafortune-Bernard, A. (2017). Promoting the Protection, Preservation and Presentation of the Natal Landscape of the Buddha in Nepal. In P. Gunawardhana, R. A. E. Coningham, \& K. Nampoothiri (Eds.), Buddha Rashmi Vesak (Vol. 2017, pp. 13-26). Colombo: Central Cultural Fund.

Coningham, R. A. E., Acharya, K. P., \& Manuel, M. (2014). Strengthening the Conservation and Management of Lumbini, the Birthplace of the Lord Buddha, World Heritage Property (Phase II): Final Report of the First Season. Unpublished UNESCO Report.

Coningham, R. A. E., Acharya, K. P., \& Manuel, M. (2015). Strengthening the Conservation and Management of Lumbini, the Birthplace of the Lord Buddha, World Heritage Property (Phase II): Final Report of the Second Season. Unpublished UNESCO Report.

CTCA. (2014). Tourism Promotion Plan for Lumbini and Adjoining Areas: Towards Making the Buddha's Birth Places \& Associated Sites a Regional Tourism Hub (2015-2024). Kathmandu: Ministry of Culture, Tourism and Civil Aviation.

ETG. (2013). Greater Lumbini Tourism Cluster Competitiveness Strategy. Unpublished report for the World Bank.

Führer, A. (1972 reprint of 1889). Antiquities of Buddha Sakyamuni's Birthplace in the Nepalese Tarai. Varanasi: Indological Book House.

Gaige, F. H. (2009). Regionalism and National Unity in Nepal. Lalitpur: Himal Book. 
IFC. (2013). Investing in The Buddhist Circuit 2014-2018: Enhancing the Spiritual, Environmental, Social and Economic Value of the Places Visited by the Buddha in Bihar and Uttar Pradesh, India. https://www.ifc. org/wps/wcm/connect/a0b004004618b490804eb99916182e35/ Buddhist+Circuit+Tourism+Strategy+Final.pdf?MOD=AJPERES.

Joury, Y. J. (1969). A Brief on the Lumbini Development Project, April 1969. Kathmandu: UN Resident Representative Office.

Lafortune-Bernard, A., Coningham, R. A. E., Acharya, K. P., \& Kunwar, R. B. (2018a). Benchmarking the Social and Economic Impact of Pilgrimage at the site of Tilaurakot-Kapilvastu (Nepal). In P. Gunawardhana \& R. Coningham (Eds.), Buddha Rashmi Vesak Volume 2018. Colombo: Central Cultural Fund: $85-96$.

Lafortune-Bernard, A., Coningham, R. A. E., \& Acharya, K. P. (2018b). Recording the Social and Economic Contribution of Local Heritage at Tilaurakot: A Pilot Study. In Oriental Cultural Heritage Sites Protection Alliance \& M. Richon (Eds.), The Cultural Heritage of Nepal, Before, During and After the 2015 Earthquakes: Current and Future Challenges. Kathmandu: Vajra Books and Oriental Cultural Heritage Sites Protection Alliance.

Lewer, N., \& Lafortune-Bernard, A. (2017). Dohani Community Consultation 13 th-16th January 2017. Coral Associates and Durham UNESCO Chair Unpublished Report.

Mukherji, P. C. (1901). A Report on a Tour of Exploration of the Antiquities of Kapilavastu Tarai of Nepal During February and March 1899. Calcutta: Office of the Superintendent of Government Printing.

Tange, K., \& URTEC. (1978). Master Design for the Development of Lumbini, Phase II. Final Report. New York: UN.

TRC. (2013). Tourism Cluster Analysis for Nepal Competitive Industries Diagnostic: Cluster Diagnostic Notes: Greater Lumbini \& Palpa and Manaslu \& Gorkha Clusters. Volume 1: Analysis. Unpublished Report for the World Bank.

UNDP and Government of Nepal. (2014). Nepal Human Development Report 2014: Beyond Geography Unlocking Human Potential. http://www.hdr.undp. org/sites/default/files/nepal_nhdr_2014-final.pdf.

UNFCO. (2013). District Profile: Kapilavastu, Nepal. http://www.un.org.np/ sites/default/files/kapilvastu_district_profile.pdf.

Uttar Pradesh Tourism. (2018). Annual Tourist Visits Statistics 20132017.http://uptourism.gov.in/pages/top/about-up-tourism/ yearwise-tourist-stats.

Vivekanda, B. (2017). Environmental Issues and Protection in Lumbini. Conference Presentation at Pathways to the Protection and Rehabilitation of Cultural Heritage in South Asia, Kathmandu, September 2017.

Whelpton, J. (2005). A History of Nepal. Cambridge: Cambridge University Press. 
Weerasinghe, J. (2017). Sigiriya World Heritage Site. Global Heritage Commodified and Local Heritage Forgotten. Conference Presentation at Pathways to the Protection and Rehabilitation of Cultural Heritage in South Asia, Kathmandu, September 2017.

Weise, K. (2013). Strengthening Conservation and Management of Lumbini, the Birthplace of Lord Buddha, World Heritage Property: Integrated Management Framework. Kathmandu: UNESCO.

Open Access This chapter is licensed under the terms of the Creative Commons Attribution 4.0 International License (http://creativecommons.org/licenses/ by $/ 4.0 /$ ), which permits use, sharing, adaptation, distribution and reproduction in any medium or format, as long as you give appropriate credit to the original author(s) and the source, provide a link to the Creative Commons license and indicate if changes were made.

The images or other third party material in this chapter are included in the chapter's Creative Commons license, unless indicated otherwise in a credit line to the material. If material is not included in the chapter's Creative Commons license and your intended use is not permitted by statutory regulation or exceeds the permitted use, you will need to obtain permission directly from the copyright holder.

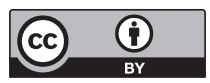

